\title{
Educational Transformation: An Evaluation of Online Learning Due to COVID-19
}

\author{
https://doi.org/10.3991/ijet.v16i07.21201 \\ Rizky Firmansyah ${ }^{(凶)}$, Dhika Maha Putri, Mochammad Galih \\ Satriyo Wicaksono, Sheila Febriani Putri, Ahamad Arif Widianto \\ Universitas Negeri Malang, Malang, Indonesia \\ rizky.firmansyah.feeum.ac.id \\ Mohd Rizal Palil \\ Universiti Kebangsaan Malaysia, Selangor, Malaysia
}

\begin{abstract}
This study aims to reveal the transformation of offline learning to online learning due to Covid-19 in student perceptions. The massive impact on the education sector requires the provision of education to adapt to situations and conditions. This research was conducted at one of the state universities in Indonesia, with the selection of informants based on the representation of each department at the university. The method in this research uses a narrative approach. The data were collected through interviews that were set up online. The research data was processed based on the results of studies and focus group discussions (FGD) related to the implementation of online learning during the Covid-19 Pandemic. The results showed that the implementation of learning was welcomed by the students, in their perception that online learning was considered to be more flexible, efficient and effective in the use of time as well as in terms of costs and energy. It cannot be denied that the implementation of online learning still encounters various obstacles and challenges, including: interaction is not optimal, schedule and lecture estimates change, inadequate facilities, and the use of learning media is not optimal.
\end{abstract}

Keywords-Educational Transformation, Covid-19, Student's Perception, Online learning

\section{Introduction}

In the last decade, the education sector in Indonesia has experienced a transformation of learning, from face-to-face learning to technology-based learning (IT). IT-based learning has been carried out in a number of educational institutions. However, in the implementation of learning, IT is only act as a supporting component and has not become part of the introduced curriculum [1][2]. Since the outbreak of the corona virus in Indonesia in March 2020, various forms of policies have been issued by the government and universities in Indonesia to be able to carry out learning activities to reduce the rapid spread of the virus. The education sector seemed to change in just one night, 
because learning activity which should have been done face-to-face, immediately had to be done in full online [3].

The rapid change brings anxiety to both educators and students and there is also ambiguity about the implications of online learning for educational equality in general [4]. They also have to change the learning contract that is applied since the first meet in the classroom, and in the end, the implementation of learning through evaluation of learning must be changed completely. In the previous research, Ali highlighted the implications of online learning in terms of its weaknesses, including inadequate online teaching infrastructure, a lack of educator experience, and information gaps [5]. In a condition like this, the readiness of education is the stakes for success in achieving learning objectives, and perhaps all obstacles experienced today are a manifestation of less anticipatory implications of previous learning. Thus, the implementation of learning before the pandemic is considered too rigid or less flexible and only depends on certain conditions, as if during the outbreak of this virus, many education providers and stakeholders in it are not ready for a different learning model, which requires full online learning.

This is not only felt by education sector in Indonesia, in various parts of the world there are still many countries that are not ready for this condition. One of them is India, its educators also feel confused about overcoming this pandemic, especially practicalbased learning materials that cannot be implemented with the same teaching method [6], [7]. Even so, the challenges facing the education today should not be a barrier, but rather a momentum for the education sector to create a concept of sustainable learning in improving the quality of education services in the future [5], [7]-[9].

Since the issuance of the Decree of the Minister of Education and Culture Number 719/P/2020 about Guidelines for Implementing Curriculum in Education Units in Special Conditions, which confirms that the implementation of the curriculum in Special Conditions aims to provide flexibility for the Education Unit to determine the curriculum that suits the learning needs of students [10]. By that, the change in implementation to the online learning method allows educators and students to continue learning, despite the limitations of both private facilities, educational institution facilities, and public facilities. All forms of any obstacle can be overcome if educators can play an active role, because one of the success factors in the application of education is the role of educators, despite the fact that the various challenges faced when teaching online are significant, at least educators can maintain communication with students to support the effective learning process [11], [12].

In the online learning system, many demands are placed on lecturers and their duties are not only teaching and presenting to students. The current situation, which does not provide certainty, presents challenges that are both ambiguous and confusing for the implementer. On one hand, lecturers are required to use and explore the possibilities of online education, starting from changing the arrangement of online learning programs, and choosing the right platform to evaluating students [13]. Meanwhile, on the other hand, the lecturers' knowledge and expertise in implementing online learning is lacking, which goes hand in hand looking at the level of ability and psychology among students, causes concern that poor implementation of online learning will have a negative impact on online learning models in the long run [14]. 
The active role of educators in learning and the ability to operate IT in order to realize effective learning should have been mastered since before the outbreak of the corona virus, this is because the education sector has long known the term e-learning. E-learning as a learning activity using telecommunication technology has been recommended to be implemented for universities in Indonesia, in accordance with the Decree of the Minister of National Education (SK MENDIKNAS) of 2001 concerning the recommendation of implementing distance education (dual mode) [15], [16]. It's just that many parties, including educators, are complacent in their comfort zone to stick with traditional learning, considering that the Minister of National Education Decree is not a must. This is certainly a slap for all stakeholders so that they are no longer complacent and feel that they are in the comfort zone, however, it is necessary to continue to improve their quality and capabilities according to the times. If only this awareness had existed before the outbreak of Covid-19, at least this could be a provision to reduce gaps as a result of the transformation of learning.

\section{$1.1 \quad$ Study objectives}

The transformation of the education sector in Indonesia due to covid-19 is faced with uncertain conditions, because the pandemic cannot be predicted when it will end, as well as new challenges and problems that cannot be avoided [5], [17]. In this case, aspects of unpreparedness and proficiency in using technology are the main factors in the implementation of education. Whereas education in the 21 st century has indicated that the implementation of education must present collaborative learning content in order to prepare students to face challenges in the 21 st century, one the ways is the use of technology [18]. The intended collaborative learning content must contain four (4) things, namely Communication, Collaboration, Critical Thinking and Problem Solving, and Creativity and Innovation. Even so, under these conditions there are still many opportunities that must be exploited to produce a sustainable learning method. Therefore, conditions like this really need an analysis of online learning that can be used as evaluation material for educational institutions and universities in Indonesia.

This article attempts to describe the state of learning carried out at a higher education institution in Indonesia since the outbreak of the Covid-19 pandemic. The purpose of this study is to determine the real conditions of online learning that have been carried out based on the perspective of students as actors who experience it directly. The results of the analysis of this research are expected to be considered for Higher Education for the implementation of online learning after the Covid-19 pandemic.

\subsection{Significance of the study}

The results of this study are very important for stakeholders in the Higher Education environment. Especially there is a limitation of previous research which states that webbased learning in Indonesia is only a support in the learning process and in its implication it is still not optimal because it tends to be more comfortable using the traditional face-to-face learning method. When Covid-19 broke out, it turned out that the concept 
of learning that was comfortable was not properly implicated in situations and conditions like this. Assessment of learning based on student perceptions is needed, considering that students are actors in implementing online learning during the pandemic, so that the advantages and disadvantages of online learning according to students can be used as evaluation material for the campus. This study will help to reveal how the educational transformation process, especially that occurs in higher education institutions that carry out full online learning, then later on can be used by authorization through its policies for the education they will run. Not only that, these results also provide insight into integrated and accommodated learning through ICT which allows higher education institutions to strengthen their programs to prepare lecturers in the face of various urgencies during the pandemic or post-Covid-19 pandemic. Meanwhile, for lecturers, they will realize the importance of mastering information technology and learning platforms to improve their sustainable teaching skills. If these results are applied, it will enable stakeholders at Higher Education institutions to create an interactive and fun learning environment for students amidst strict national regulations.

\section{The Implication of Behavioristic Theory on Online Learning}

The change of the learning process using distance learning methods requires that both educators and students need to make many adjustments and learn a lot of new things. When the speed of significant change is not directly proportional to the speed of the ability to adjust, it can lead to unpreparedness problems. One of the things that is imperative in online learning is the availability of adequate facilities and no less important is the ability to operate the required technology. Unpreparedness, both in terms of facilities and operational capabilities, ultimately becomes an obstacle in the online learning process. Two things are just a small part of the many obstacles faced by educators and students; it is necessary to further studies to gain insights into what things are already happening during the learning process. For stakeholders involved in education, it is a new problem that should be cut out immediately for the sake of the learning goals achievements that standardized and accommodated well.

Until now, the flow of learning psychology which is considered to have an influence on the development of theory and practice of education and learning is the behavioristic school [19]. Behavioristic learning theory is a learning theory that emphasizes changes in behavior with the main element of response stimulus focusing on new behavior patterns that are repeated until they become cultured behavior [20]. The stimulus and response given by educators should aim to invite students' reactions that can be observed and measured known as responses. Thus, the obstacles regarding the unpreparedness of the operation of technology can be resolved by applying the principles of behavioristic theory in learning by creating positive behavior in the learning environment.

The stimulus referred to in behavioristic theory can be in the form of good and planned learning. A good and planned learning program is normally in the form of learning equipped with multimedia and learning designs to help students achieve learning goals. Multimedia and quality learning designs must be developed based on a clear 
scientific foundation to get good quality learning. The application of behavioristic theory in technology has produced many learning designs that become the basis for new learning models to improve the quality of learning [21]. So, the barriers to online learning in terms of facilities should be resolved by adopting behavioristic theory principles.

However, the sensitivity and foresight of educators are needed in the application of behavioristic theory principles [22]. This sensitivity and foresight are aimed at ensuring that the steps taken in applying the principles are correct. These steps start from determining goals, environmental analysis, determining and presenting material, providing a stimulus, observing responses, providing reinforcement and new stimulus, to evaluating. In the end, behavioristic theory can be used as a basis for developing a learning design that is in accordance with current needs both to form the expected learning behavior as well as the development of quality multimedia.

\section{$3 \quad$ Method}

\subsection{The approach of research}

This research uses a narrative approach. A narrative research has many kind, and rooted in the discipline (science) of different human and social [23]. Narrative can mean the theme given to a text or discourse that is used in a context or form of inquiry in qualitative research [24]. The results of this research is an evaluation of the education transformation before a pandemic covid-19, towards fully online learning based on student perceptions. Narrative research is the study of individual lives told through stories that are meaningful in their experiences [25]. Meanwhile, narrative is a research method in the social sciences. The essence of this method, to understand a person's identity and world view by referring to the stories (narrative) that the person was listens to or even tells in everyday activities [26]. Based on that, this study tries to illustrate student experiences related to online learning during the Covid-19 Pandemic.

\subsection{Data collection}

Types and sources of data used in this study include primary data and secondary data. Primary data is processed from the results of studies and focus group discussions (FGD) with students related to the implementation of online learning during the Pandemic. Data collection is carried out synchronously using the WhatsApp-call and Google-meets. It is necessary to adjust the remote data collection method, considering that this research was carried out during the Covid-19 Pandemic. Meanwhile, the selection of informants is based on the representation of each department in the university which is used as the object of research.

Secondary data in this study are (a) government regulations regarding the learning process of Higher Education during the Covid-19 pandemic; (b) Policies of educational institutions related to the learning process during the Covid-19 Pandemic; (c) online learning content during the Covid-19 Pandemic; (d) online student learning outcomes 
during the Covid-19 pandemic; and (e) news related to the teaching and learning process during the Covid-19 Pandemic. Secondary data of the research were obtained from the results of literature review through search engines. The data used is also relatively new according to the Covid-19 pandemic. Literature review is used as a comparison between student learning experiences and the readiness of education. This comparison will examine the extent to which educational institutions preparing online learning during the Covid-19 pandemic, as well as how the result students in learning online have been done.

\subsection{Data analysis}

The data analysis in this study used an interactive model expressed by Miles and Huberman (1992). It is hoped that this model can tell a narrative about the transformation of education that occurred in one of the higher education institutions in Indonesia which used full online learning during the Covid-19 pandemic.

After the data was collected, the researcher examined the answers of each informant from each department. The results of the analysis of answers are used to map the narrative that will be presented in the results and discussion of the research. The results of the interviews that had been reduced were further examined through a focus group discussion (FGD). Then draw conclusions.

\section{$4 \quad$ Result and Discussion}

Covid-19 has made many significant changes in just a short time. This phenomenon encourages change and policy reform in various sectors of life, one of that is education sector. These changes and policy reforms have led humans to enter a new phase of life known as New Normal Live with an uncertain period of time [27]. This uncertainty makes learning planning tentative, but it's clear that the pandemic is changing the way we live, learn and work [14].

Online learning systems as a synchronized and unsynchronized distance learning model are not new in the education sector. Before the pandemic, this system was only used as an addition to support traditional face-to-face education because of the unpreparedness of its resources or facilities or maybe worried about technical or non-technical disturbances that could interfere with student communication with lecturers, so that the programs or teaching materials delivered by lecturers were not optimal [2]. The certainty of the end of the pandemic is very uncertain, meaning that the implementation of returning to face-to-face (offline) learning as was usually done before, will also experiencing uncertainty. This gives a positive signal that the online learning option will continue for a long time. Therefore, improving the quality of online learning is a necessary step at this time [28].

The Ministry of Education and Culture of the Republic of Indonesia has encouraged higher education institutions to carry out online learning, in order to alleviate the spread of the rapidly growing virus. It is hoped that the savings in operational costs of educa- 
tion that are obtained during learning from home can be used to help students and lecturers [29]. Assistance can be in the form of learning support facilities such as internet data and also in the form of logistical assistance for students who are unable to return home in the midst of the Covid-19 pandemic for various reasons, such as an appeal not to return home from the campus or area of origin, cost constraints, to internet access problems at hometown that does not support the implementation of online learning.

Universitas Negeri Malang (UM) is one of the state universities in Indonesia that also implements online learning. A total of 80 informants stated that learning at the university had been carried out in full online learning. This learning model was welcomed by students, because most the students stated that they were ready to do online learning. Their readiness in welcoming online learning is certainly supported by the learning facilities that they have, including devices (cellphones, laptops, desktops, etc.) and internet connections. Anisa, one of the university students, revealed:

"Alhamdulillah, in terms of facilities such as a laptop and internet data I am ready, while the environmental conditions at home are very support to get a strong internet network"

The readiness of student learning facilities will also be a problem if the way they use is not appropriate, because there is the possibility that at one time they can access various activities. Meanwhile, students expressed their unpreparedness in carrying out online learning, due to several factors both internally and externally which became a special challenge in the middle of a situation like this. As Rochmad said that house as his new place of learning was not supportive, because there were many disturbances such as the sound of chickens, the sound of cows and vehicles. In addition, he is also concerned about where he lives because he does not have a strong internet network. Not a few students have experiences like Rochmad, as a result, their learning focus is disrupted and the material presented by the lecturers is left behind. Based on the informant's explanation, the outbreak of Covid-19 in Indonesia has reaped pros and cons in applying the current learning model. In the next discussion, interesting facts will be presented regarding the implementation of online learning during the Covid-19 pandemic.

\subsection{Learning implementation during Covid-19 pandemic}

Online learning as a new policy for the education sector provides an opportunity to continue to be able to carry out learning in situations that do not allow face-to-face implementation. Online learning has many obstacles, because changing habits from face-to-face to completely online raises many needs that must be fulfilled. In a transitional phase like this, educators have a big role in the implementation of learning. The role of educators is not only to teach and as facilitators, but educators are required to be critical and active in following and being part of the latest technological developments. The adoption of technology is important and is one of the mandatory needs that must be fulfilled in a situation like this to support the learning process [30]. The needs referred to include the availability of infrastructure, improving system quality, the ability to operate technology, new learning tools, and most importantly how to implement an effective and efficient online learning method. 
In a situation like this, technology is only a bridge for lecturers to transfer knowledge to students. The interaction model can also be done through a learning platform, such as: Google-meet, Zoom and also asynchronously, such as Google-classroom, Whatsapp, Line, and so on. Based on the information conveyed by the informants, the learning media used by lecturers and students was a mixture of synchronous and asynchronous. This is intended to match the learning needs of students. The learning method used is only one synchronous or asynchronous interaction model. According to the informants' admission, this was based on several reasons, namely the unstable network that allowed them to carry out asynchronously or they felt uncomfortable if the learning was only provided with material without introductory material and explanation.

The learning interaction model that has been implemented has drawn several assessments and criticisms, resulting in ambiguity regarding the implications of online learning. The following will describe specifically what things happened in the learning process during the transition to continuous learning.

Students are more active outside the class: During the application of the online learning model, students get more flexibility in time. This condition requires them to be able to control themselves, because in achieving a goal in taking learning is done independently. Learning independently automatically gives students the opportunity to use the learning style they feel is most appropriate and provides wide opportunity for students to further explore their curiosity based on their respective interests and needs. This statement was further strengthened by Febri:

"This online learning makes me more diligent, because I have less time to study with the lecturers and it is not certain that I can understand all the lecturers' explanations synchronously."

Other informants also felt Febri's experience, so it could be said that students had more opportunities to take the initiative to find and use other references independently to support their understanding of learning materials. Especially during the learning process is done online, the media and other sources of learning provided lecturers are designed to fulfill the learning needs of the students so that students can access and utilize more and repeat it as they needed. Therefore, in students' perceptions, online learning is considered to have time flexibility which is seen as an advantage of implementing online learning [31], as well as efficiency in costs and energy, and unexpectedly the implementation of online learning actually has a positive impact on student learning independence [32].

Students' challenge during transition time: In the transition from face-to-face learning to online learning, students must really pay attention to how to adapt to their new place of learning. The mindset that is embedded in their minds, that the house is not a place that is entirely for doing assignments, then must be used as a comfortable place for them to study. The situation is changing too fast and seems forced which makes students feel "learning shock". With conditions that describe students who are faced with learning methods that are not usually applied with a lot of assignment instructions that have never been obtained before. The change of this atmosphere that will have an impact on students" psychology and in the end this "learning shock" will make students feel confused, anxious and frustrated. 
"The rapid change to online learning makes us anxiety and shock because we are not used to using online platforms for study. We have to adapt to the current learning needs and indeed force us to adapt", said Mario.

For students, the flexibility of time in the online learning implementation is seen as the advantages of online learning. Unfortunately, it is seen like a double-edged knife. Flexibility is not only an advantage but also a disadvantage. It depends on whether the students are using the time flexibility properly or not. Only students who have high motivation and enthusiasm for learning are likely to be able to make good use of opportunities for productive things, especially to support their learning process. This is because the learning motivation that a person has tends to influence the decisions to be taken, including what they learn, how learning styles, and when to choose to study [33], whatever the problems will be faced in order to achieve the expected goals. On the other hand, for students who lack enthusiasm for learning, time will be wasted because it is not used for positive things.

In addition to the problem of how time can be used properly, obstacles in the online learning process are still uncontrollable, such as lack of adequate facilities, disruption of internet networks, disruption of software and platforms, especially for learning using video conference. Its implementation is clearly more limited by a short period of time, with the aim of cutting internet costs that must be incurred. Not to mention the obstacles for practicum courses which should have been carried out in the laboratory but had to be forced to be held online [34]. This is in line with Haydhar's disclosure from the Mathematics and Science Faculty student:

"We have difficulty understanding theories and concepts if there are no video lessons, especially for courses that should have practicum in the laboratory, but must be replaced with distance learning. While giving assignments as a substitute for practicum, I feel that I did not get much knowledge because after all, the practicum still has to be done to gain experience and provision for me in the future."

Not only on the faculty of Mathematics and Science, other majors who have practicums were also feel the same way, how hard it is to understand the material if it's not be practiced. For them, practice-based material really needs a practicum program that is carried out directly in the laboratory or in the field. This is the evidence that the urgency of lecturer teaching methods is vital for current conditions, so it is necessary for the lecturers to be more concern about this so as not to reduce the essence of the material in courses, especially those that require practicum. Lecturers need to provide various learning resources that make it easier for students, especially practicum material, which can be in the form of learning videos or other interactive media.

The teaching practices of lecturers and the impact on students: The important point of learning is that it takes place in a two-way process, so there is active feedback between lecturers and students [35]. But the real implication, students feel it is still minimal practiced which leads to a lack of their understanding towards the learning material. Educators are considered to only provide assignments without clear instructions and reference sources. Of course, this causes confusion and discouragement for students in following all the learning sequences that have been arranged by the lecturer. When they were asked to state which platform was the most convenient, the responses received varied according to their needs and experiences. 
Based on the informants' admission, their understanding during online learning was considered not good enough. There is nothing wrong, if students assess the quality of online learning as no better than face-to-face learning. Most of them think, they do not get the essence of a matter as a whole. Even according to the confessions of several informants, there were still many lecturers who had not mastered the technology or platform used to interact optimally. In addition, there were many obstacles and adjustments that had to be made by the lecturers, often causing the learning process to not run properly and not according to what had been scheduled. Not to mention, lecturers who often exaggerate their time when conducting video conferences, making it difficult for students to prepare for the next class schedule and in the end their schedules become pile up. The impact is not only in terms of time and costs incurred, their energy and thoughts will also be disturbed, as a result the learning process is not achieved optimally [36]. It is undeniable that the conditions of online learning have certain limitations, this is what makes some lecturers often give course assignments, even students think that the assignments given during online learning are far more than normal face-to-face lectures.

Student assesments of the quality of lecturers' teaching was only categorized as "good enough". It's mean that there is still a plus-minus of lecturers' teaching methods or strategies that must be immediately evaluated to imply a sustainable distance learning method. In current teaching methods, it is the aspect of readiness and technology that are the main factors in maintaining the lecturers' teaching performance. For Faricha, the readiness of lecturers and the main media used very influential in the learning process of students, as well as evaluations or assignments given lecturers need to be considered again, whether by the media and the method used previously are correct or not. At a minimum, there needs to be an evaluation in order to be much more effective for the next learning. Furthermore, Faricha also highlighted the learning methods and strategies applied by lecturers in the online system:

"Supposedly, before students are given the task, lecturers can give a case to be analyzed first before finally discussed through video conference, rather than having synchronous learning for two hours full even exaggerated, but the purpose of the learning process is not optimal."

Several other informants also said that there are still many lecturers who are less than optimal in the use of technology. As a result, the learning media used by students was not optimal. Considering that in this online learning system, IT -based media is very much needed, then learning media that is attractive and easy to understand will make students more comfortable like learning when in class directly. Not only the media that become a spotlight for students, but also the assignment/project that lecturers are given. Students are desperately need evaluation/discussion more to know whether their works are correct or not. Therefore, before compiling the learning tools, lecturers need to consider the methods and learning media that will be used by looking at various aspects and especially the needs of students in order to maintain quality and achieve learning effectiveness. 


\subsection{Online learning students are expecting}

When students were asked to choose between online learning and learning face to face, there are differences in choice of learning in what students want. Actually, achieving goals in online learning is not only support from lecturers or other external factors, but factors that exist within the students also have a very big influence, but those factors within the students also have the massive impact. One of that is to adjust to the learning model at this time. Alby, one of the students really welcomes online learning:

"I prefer online, because from an efficiency, effectiveness and time productivity perspective, it can be obtained. It remains how to instill habits between individuals."

Disagree with Panji, he prefers face-to-face learning because it makes it easy to access a variety of sources, and will be more effective to subjects that require practicum. Several other reasons expressed by students who chose face-to-face learning, including the lecturer's voice was clearer when explaining the material, discussions could run normally and they received direct feedback from the lecturer. Furthermore, they mentioned that one-roof learning was felt to raise their motivation and required full concentration to listen to the material, so it required a continuous focus of attention. It is different from the implementation of online learning which must coincide with the daily activities of students, which at times will make the focus of attention on learning divided into their activities [37]. When they $\log$ in to an online class, there is a possibility that they are doing other assignments or maybe they are helping their parents work. This is beyond the control of the lecturer, because environmental factors are also one of the causes for the decrease in the focus of student attention. Thus, since learning is a goal of teaching, study, and learning also depend on the students' attention, that means to be a specific challenge for the lecturers to create a sustainable online learning.

However, these conditions will always be a necessity in the future and we will not be able to avoid the demands of the times, especially those that require the use of IT. With this, education in the future is expected to depend on technology, because no one will know what happen in the future. There is another unique thing that needs to be the focus of this research discussion, that many of the informants advised lecturers to consider the blended learning model. In their perception, maybe courses that only require deepening of material or theory can be done online, while materials that require practical work need to be done face-to-face with strict attention to health protocols. Referring to the previous informant's admission, we conclude that the essence of practicum material cannot be replaced if it is only replaced by an assignment or anything similar. This is further strengthened by Amalia's statement:

"The blended learning model will run normally if it is supported by effective lecturer delivery methods and learning media that can support the implementation of the blended learning model, for example the use of instructional videos, giving pre-tests, and clarity of teaching schedules from lecturers."

Blended learning as a combination of online learning methods and face-to-face learning is considered to be able to help the student learning process well and improve self-direct learning abilities [35]. In creating optimal blended learning, lecturers need to strive to find new innovations in implicating learning methods and media, because after all, only technology is the bridge for lecturers to provide knowledge to students in 
situations like this or in different conditions in the future. Several informants mentioned that learning media is the main factor that can determine how learning material can be successfully conveyed.

"We hope that lecturers will improve the quality of their teaching and innovate in the media and learning devices. Especially for material that requires practice, if it is not possible to do it directly in the laboratory, at least the lecturer provides clear instructions through a learning video", said Icha.

Delivering material through demo videos or discussions stimulated by giving cases at the beginning of the lesson is considered to be able to support students' thinking processes. It's good if the assignments can be given after the essence of a material conveyed well, because some students feel assignment cannot make them understand the material well or even can make them commit to cheat in the settlement. This form of cheating motive arises due to minimal deadlines to complete their assignments and students also have other assignments from different lecturers. Apart from the advantages and disadvantages, the success of online learning is also determined by the active interaction between lecturers and students, how discussions can be developed and the learning result becomes meaningful [38].

\section{Conclusion}

Based on the narrative description of this research, we already know an overview implementation of online learning at one of the state universities in Indonesia has emerged various pros and cons. In terms of strengths, online learning is considered to have flexibility in managing student learning spaces, but it will be a weakness if there is no will from within each individual. Meanwhile, in terms of weaknesses, there are many things that must be the focus of attention for stakeholders, starting from unpreparedness of facilities, limitation mastery of technology to psychological problems felt by students. Overall, the various challenges faced lead to the effectiveness and efficiency of sustainable online learning. In achieving the effectiveness of learning, it is necessary to make adjustments and improvements made on various sides, starting from educational institutions as authorization, educators and students. Lecturers are expected to pay special attention to the obstacles faced by students, facilitate learning with attractive and easily accessible reference sources, prepare learning tools that have been adapted to current conditions, and provide assignments equipped with clear material introductions and instructions [39]. In a study by Samarraie et al. Stated that satisfaction with online learning systems can affect their level of satisfaction with practical experiences developed by their university [40]. This research will provide awareness for educators that a condition like this or conditions that may be different in the future, will always need technology as an eternal companion in bridging knowledge to be distributed to students, so it is necessary for lecturers to improve their teaching quality and capacity by utilizing IT.

Referring to previous research that IT-based learning is only a support in the learning process and there is no clear guideline for the need for technology in education sector. 
Based on the evaluation of the entire process of teaching and learning activities, providing and improving learning system facilities and being open to listen to obstacles from all parties, it is important for educational institutions to immediately follow up and provide solutions through their policy initiatives. It may need to be considered and reviewed by the government that the use of technology at this time is a major requirement in the delivery of education, so specific and clear guidelines (rules) that can be generally implicated in education units are needed to be provided. With these guidelines, each education institution can apply these guidelines and develop in their institutions. It is hoped that the implementation of learning in educational units will be well integrated and accommodated, so that there are no gaps and ambiguity in the delivery of education and education services to become more standardized and have a certain quality, and also the society will see them more professionally.

This research has limitations, considering that this research was conducted during the Covid-19 pandemic, so all research processes go through long-distance communication. Whereas in this study, the main focus is how the process of learning transformation that happen in a state university in Indonesia, as well as what challenges and opportunities are faced during the transition to sustainable learning. The next research is expected to be able to examine more broadly about online learning practitioners, so that there will be suggestions or policy models that can be applied by educational institutions, especially universities in Indonesia.

\section{Acknowledgement}

We would like to express our gratitude to Universitas Negeri Malang for providing financial support in the implementation of this research.

\section{$7 \quad$ References}

[1] Y. Pujilestari, "DampakPositifPembelajaran Online DalamSistem Pendidikan Indonesia PascaPandemi Covid-19," vol. 4, hal. 49-56, 2020.

[2] K. Phirangee dan A. Malec, "Othering in online learning: an examination of social presence, identity, and sense of community," Distance Educ., vol. 38, no. 2, hal. 160-172, 2017. https://doi.org/10.1080/01587919.2017.1322457

[3] B. Indrawati, "Tantangan Dan Peluang Pendidikan Tinggi," J. Kaji. Ilm., hal. 39-48, 2020. https://doi.org/10.31599/jki.v1i1.261

[4] W. Zhang, Y. Wang, L. Yang, dan C. Wang, "Suspending Classes Without Stopping Learning: China's Education Emergency Management Policy in the COVID-19 Outbreak," J. Risk Financ. Manag., vol. 13, no. 3, hal. 55, 2020. https://doi.org/10.3390/jrfm13030055

[5] W. Ali, "Online and Remote Learning in Higher Education Institutes: A Necessity in light of COVID-19 Pandemic," High. Educ. Stud., vol. 10, no. 3, hal. 16-26, 2020. https://doi.org/10.5539/hes.v10n3p16

[6] T. Heyang dan R. Martin, "Research in Dance Education A reimagined world: international tertiary dance education in light of COVID-19," Res. Danc. Educ., vol. 00, no. 00, hal. 115, 2020. https://doi.org/10.1080/14647893.2020.1780206 
[7] P. K. Jena, "Impact of Pandemic COVID-19 on Education in India," Int. J. Res. Commer. Manag., vol. 5, no. 10, hal. 7-11, 2020, doi: 10.24941/ijcr.39209.07.2020.

[8] P. K. JENA, "Challenges and Opportunities created by Covid-19 for ODL: A case study of IGNOU," Int. J. Innov. Res. Multidisiplinary F., vol. 6, no. 5, hal. 217-222, 2020. https://doi.org/10.31235/osf.io/jy2td

[9] A. M. Schwartz, J. M. Wilson, S. D. Boden, T. J. M. Jr, T. L. B. Jr, dan N. D. Fletcher, "AOA Critical Issues in Education Managing Resident Workforce and Education During the Evolving Strategies and Lessons Learned," Am. Orthop. Assoc., hal. 1-5, 2020. https://doi.org/10.2106/jbjs.oa.20.00045

[10] Kementerian pendidikan dan kebudayaan republik indonesia, "Keputusan menteri pendidikan dan kebudayaan republik indonesia nomor 719/p/2020 tentang pedoman pelaksanaan kurikulum pada satuan pendidikan dalam kondisi khusus menteri," Jakarta, 2020. https://doi.org/10.24832/ipnk.v16i9.520

[11] P. J. Palmer, The courage to teach: exploring the inner landscape of a teacher's life. San Francisco, Calif: Jossey-Bass, 1998. https://doi.org/10.5465/amr.1999.1893945

[12] J. König, D. J. Jäger-biela, N. Glutsch, dan D. J. Jäger-biela, "Adapting to online teaching during COVID-19 school closure: teacher education and teacher competence effects among early career teachers in Germany early career teachers in Germany," Eur. J. Teach. Educ., vol. 00, no. 00, hal. 1-15, 2020. https://doi.org/10.1080/02619768.2020.1809650

[13] A. Irhandayaningsih, "PengukuranLiterasi Digital Pada PesertaPembelajaran Daring," UNDIP E-JOURNAL Syst., vol. 4, no. 2, hal. 231-240, 2020, [Daring]. Tersedia pada: http://ejournal.undip.ac.id/index.php/anuva\%0APengukuran

[14] H. Khalili, "Online interprofessional education during and post the COVID-19 pandemic: a commentary," J. Interprof. Care, vol. 00, no. 00, hal. 1-4, 2020, doi: $10.1080 / 13561820.2020 .1792424$.

[15] W. Hartanto, "Penggunaan E-Learning Sebagai Media Pembelajaran," no. 3.

[16] A. Ihwanah, "IMPLEMENTASI E-LEARNING DALAM KEGIATAN PEMBELAJARAN PGMI IAIN SULTHAN THAHA SAIFUDDIN JAMBI," Cakrawala, vol. XI, no. 1, hal. 76-91, 2016. https://doi.org/10.31603/cakrawala.v11i1.102

[17] J. M. Fegert, B. Vitiello, P. L. Plener, dan V. Clemens, "Challenges and burden of the Coronavirus 2019 (COVID - 19) pandemic for child and adolescent mental health: a narrative review to highlight clinical and research needs in the acute phase and the long return to normality," Child Adolesc. Psychiatry Ment. Health, vol. 14, no. 20, hal. 1-11, 2020. https://doi.org/10.1186/s13034-020-00329-3

[18] R. D. Prayogi dan R. Estetika, "Kecakapan Abad 21: Kompetensi Digital Pendidik Masa Depan,” J. Manaj. Pendidik., vol. 14, no. 2, hal. 144-151, 2019, doi: 10.23917/mp.v14i2.9486.

[19] E. B. Shahbana, F. kautsarFarizqi, dan R. Satria, "ImplementasiTeoriBelajarBehavioris-tikDalamPembelajaran,” J. Serunai Adm. Pendidik., vol. 9, no. 1, hal. 24-34, 2020.

[20] N. Nahar, "PenerapanTeoriBelajarBehavioristikdalam Proses Pembelajaran," Nusant. J. IlmuPengetah. Sos., vol. 1, no. 1, hal. 64-74, 2016.

[21] D. Hardianto, "ParadigmaTeoriBehavioristikdalamPengembangan Multimedia Pembelajaran,” Maj. Ilm. Pembelajaran, 2012.

[22] Umar, "AnalisisKonstruktifTeoriBelajarBehaviorismedalam Proses Pembelajaran di Sekolah,” EL-muhbib J. Pemikir. dan Penelit. Pendidik. dasar, vol. 2, no. 1, hal. 41-51, 2018.

[23] J. W. Creswell, Qualitative inquiry and research design: Choosing among five approaches, 2nd ed. Thousand Oaks, CA, US: Sage Publications, Inc, 2007. 
[24] S. E. Chase, "Narrative Inquiry: Multiple Lenses, Approaches, Voices.," in The Sage handbook of qualitative research, 3rd ed., Thousand Oaks, CA: Sage Publications Ltd, 2005, hal. $651-679$.

[25] J. Schreiber dan K. Asner-Self, Educational research: the interrelationship of questions, sampling, design, and analysis. Hoboken, NJ: Wiley, 2011.

[26] L. Webster dan P. Mertova, using narrative inquiry as a research method: An introduction to using critical event narrative analysis in research on learning and teaching. New York, NY, US: Routledge/Taylor \& Francis Group, 2007. https://doi.org/10.4324/9780429424533

[27] J. Allen, L. Rowan, dan P. Singh, "Teaching and teacher education in the time of COVID19," Asia-Pacific J. Teach. Educ., vol. 48, no. 3, hal. 233-236, 2020. https://doi.org/ 10.1080/1359866x.2020.1752051

[28] M. P. A. Murphy, "COVID-19 and emergency eLearning: Consequences of the securitization of higher education for post-pandemic pedagogy," Contemp. Secur. Policy, vol. 41, no. 3, hal. 492-505, 2020. https://doi.org/10.1080/13523260.2020.1761749

[29] Kemdikbud, "KemendikbudApresiasiDukunganKampusKepadaMahasiswaSelamaLakukanPembelajarandariRumah," Kementerian Pendidikan dan Kebudayaan, 2020. https://www.kemdikbud.go.id/main/blog/2020/04/kemendikbud-apresiasi-dukungan-kampus-kepada-mahasiswa-selama-lakukan-pembelajaran-dari-rumah (diakses Sep 01, 2020).

[30] U. A. Chaeruman, “Alur Belajar: MeningkatkanInteraktivitasPembelajaran Daring," Semin. LokakaryaPembelajaran Daring di Perguru. Tinggi, no. September, hal. 1-10, 2017.

[31] A. Sadikin dan A. Hamidah, "Pembelajaran Daring di Tengah Wabah Covid-19," Biodik, vol. 6, no. 2, hal. 109-119, 2020. https://doi.org/10.22437/bio.v6i2.9759

[32] Firman, "Dampak Covid-19 terhadapPembelajaran di Perguruan Tinggi," BIOMA J. Biol. dan Pembelajarannya, vol. 2, no. 1, hal. 14-20, 2020.

[33] Y. Fitriyani, I. Fauzi, dan M. Sari, “JurnalKependidikan:," J. Kependidikan, vol. 6, no. 2, hal. $165-175,2020$.

[34] W. Noviati, “Jurnal Pendidikan MIPA Volume 10. Nomor 1, Juni 2020 KesulitanPembelajaran Online Mahasiswa Pendidikan Biologi di Tengah Pandemi Covid19," J. Pendidik. serambiilmu, vol. 4, no. 1, hal. 95-101, 2020. https://doi.org/10.37630/jpm.v10i1.258

[35] S. Istiningsih dan Hasbullah, "Blended Learning, Trend Strategi PembelajaranMatematika Masa Depan,” J. Elem., vol. 1, no. 1, hal. 49-56, 2015, doi: 10.30998/formatif.v4i1.140. https://doi.org/10.29408/jel.v1i1.79

[36] B. NurCita dan T. Susantiningsih, "DampakPembelajaran Jarak Jauh Dan Physical Dis-tancing Pada Tingkat KecemasanMahasiswaFakultasKedokteran Universitas Pembangunan Nasional 'Veteran' Jakarta,” J. Borneo Holist. Heal., vol. 3, no. 1, hal. 58-68, 2020.

[37] K. K. Szpunar, S. T. Moulton, dan D. L. Schacter, "Mind wandering and education: From the classroom to online learning," Front. Psychol., vol. 4, no. 495, hal. 1-7, 2013, https://doi.org/10.3389/fpsyg.2013.00495

[38] K. Swan, "Building Learning Communities in Online Courses: The Importance of Building Learning Communities in Online Courses: the importance of interaction," Educ. Commun. Inf., vol. 2, no. 1, hal. 23-49, 2002, https://doi.org/10.1080/1463631022000005016

[39] P. Wahyono, H. Husamah, dan A. S. Budi, "Guru profesional di masa pandemi COVID-19: Review implementasi, tantangan, dan solusipembelajaran daring," J. Pendidik. Profesi Guru, vol. 1, no. 1, hal. 51-65, 2020, doi: 10.22219/JPPG.V1I1.12462. https://doi.org/10. 31219/osf.io/btj7m

[40] H. Al-Samarraie, B. K. Teng, A. I. Alzahrani, dan N. Alalwan, "E-learning continuance satisfaction in higher education: a unified perspective from instructors and students," Stud. High. Educ., vol. 43, no. 11, hal. 1-17, 2017, https://doi.org/10.1080/03075079.2017. $\underline{1298088}$ 


\section{Authors}

Rizky Firmansyah, Dhika Maha Putri, Mochammad Galih Satriyo Wicaksono, Sheila Febriani Putri, Ahamad Arif Widianto are from Universitas Negeri Malang, Malang, Indonesia. E-mail: rizky.firmansyah.fe@um.ac.id

Mohd Rizal Palil is from Universiti Kebangsaan Malaysia, Selangor, Malaysia

Article submitted 2021-01-15. Resubmitted 2021-02-20. Final acceptance 2021-02-24. Final version published as submitted by the authors. 